doi: 10.52370/TISC21247IR

\title{
ASSESSMENT OF THE PANDEMIC SHOCK ON THE TOURISM SECTOR - THE CASE OF CROATIA
}

\author{
Ivan Ružićl ${ }^{1}$ Petra Popek Biškupec ${ }^{2}$
}

\begin{abstract}
Due to the pandemic crisis, the decline in cross-border travel has caused deterioration of consumption and induced the collapse of domestic consumption. Finally, the drop of the consumption in travel service affected the travel trade balance and caused decline of the economy. The aim of this paper is to analyze the impact of the pandemic shock on the touristic sector in Croatia and to measure the effect of this negative trend. The research will be conducted using the SVAR model to disclose pandemic shock. The analysis considers the effect of the pandemic shock on the performance of the tourism sector, what is approximated by CROBEX turist index. Also, the analysis tests the impact of pandemic shock on turnover of the hotel industry. The results confirm the large-scale shock in the touristic sector and implicate the importance of measuring shock in assessing future trends and proposing measures for economic recovery in Croatia.
\end{abstract}

Key Words: pandemic, touristic sector, Croatia, SVAR model, economic recovery

JEL classification: $C 13, E 60, Z 32$

\section{Introduction}

The recent pandemic has caused a deep downturn in the whole economy, and especially the slump in travel and service consumption. The greatest extent of the negative shock was to the countries that are net exporters of tourism (Canova \& Dallari, 2013).

\footnotetext{
${ }^{1}$ Ivan Ružić, PhD, Dean, University of Applied Sciences Baltazar Zaprešić, Vladimira Novaka 23, Zaprešić, 00385995239753,iruzic@bak.hr

2 Petra Popek Biškupec, PhD, Assistant Dean, University of Applied Sciences Baltazar Zaprešić, Vladimira Novaka 23, Zaprešić, 00385915670235, pbiskupec@bak.hr
} 
The COVID-19 pandemic has affected travel and service consumption worldwide and it mostly endangered the tourism-dependent countries. Many countries have restricted travel and trade due to extraordinary epidemiological conditions which caused a large drop in consumption. The negative effect of the pandemics on tourist arrivals became more obvious in emerging countries (Mekharat \& Traore, 2020). Regarding the lower level of poor health infrastructure, the tourism demand decreased immediately and quicker in low-income countries compared to developed countries. At the beginning of the COVID-19 crisis, the advanced countries were able to handle the pandemic for a certain time (Yang et al., 2020).

The lockdowns have caused the disruption of social and economic activities for billions what was manifested through economic collapse scenario. The countries with the highest level of COVID-19 infections reported the biggest rate of unemployment (Bakar \& Rosbi, 2020).

Finally, the decline in cross-border travel and deterioration of consumption induced the collapse of domestic consumption. The overall consequence was the drop of the consumption in travel service which affected the travel trade balance and caused decline of the economy.

The aim of this paper is to analyze the impact of the pandemic shock on the touristic sector in Croatia and to measure the effect of this negative trend. The research is conducted using the SVAR model to disclose pandemic shock. The analysis considers the effect of the pandemic shock on the performance of the tourism sector, what is approximated by CROBEXturist index. Also, the analysis tests the impact of the pandemic shock on turnover of the hotel industry.

The results confirm the large-scale shock in the touristic sector and implicate the importance of measuring shock in assessing future trends and proposing measures for economic recovery. The paper raises awareness of the need for further research and quantitative analysis of the impact of shock on certain segments of the tourist offer. This is necessary for the most adequate design of measures and political strategies for recovery of the tourism sector in Croatia and the economy as a whole.

In the next period, the regulators, both monetary and fiscal authorities, will have to encourage the tourism sector. For the tourism-dependent countries, the critical role in diminishing long-lasting consequences will have fiscal and macroprudential policies and unconventional monetary policy. 
Monetary and macroprudential tools could be used specifically to restart business and credit cycles and to boost economy (Popek-Biškupec, 2015). The fiscal stimulus is necessary to be well design to target the recovery of tourism sector (Goretti et al., 2021).

\section{Literature review}

The decline in travel and consumption service caused enormous gaps in the country's budgets in tourism-dependent economies. The pandemic crisis started with initial health shock that initiated a disruption in production and supply chains. After inventories were being used up, there was a breakdown of supply. At the same time, there was a drop in consumption and investment due to the fear, panic and uncertainty. A drop in demand caused a drop in a company's cash flow leading to fear of bankruptcy. Initially, to protect from bankruptcy, companies laid off employees which led to growth of unemployment. Finally, this caused a decline in the income of households and demand drop (Čavrak, 2020).

Many sectors were extremely sensitive to pandemic shock. Arčabić (2020) conclude that in the short term, the trade and services sector were the most exposed. According to this analysis, the trade and service sectors are net transmitters of shocks and the spillover of shocks in that sector is stronger, what in the long-run period may cause structural damage to the macroeconomic system.

Due to the COVID-19 pandemic, the tourism sector suffered huge losses and many subjects were in shutdown. At the global level, there is an estimation of 75 million job losses in the tourism and hospitality sector (Newsome, 2020). Uğur and Akbiyik (2020) reveal that the subjects in tourism sector suffered profound consequences because of sudden canceling trips, absence of new demand and inability to reorient to another type of work.

The long-term consequences of a pandemic shock will manifest in all segments of the economy. The deep difficulties caused by the exposure of public finances will have a negative effect on the recovery and will certainly prolong the turn-ups in business cycles. EU countries are affected at different intensities, so the responses of regulators are different. However all countries have focused on fast and significant fiscal packages in collaboration with unconventional monetary policy instruments (Praščević, 2020). 
Bakar and Rosbi (2020) evaluated the impact of pandemic crisis "using supply and demand curve to detect the economic changes in tourism industry" (p. 4). The results show that COVID-19 created panic among public what contributed to lower demand in tourism industry. Brida et al. (2020) tested the different dynamics of economic growth and tourism, the connection between economic growth numerous direct and indirect channels of touristic products. For the analysis, authors constructed two groups of countries sharing similar performance according to high or low performance in the tourism sector. The dynamics showed that the low performance cluster tends to spread, and that the high-performance countries gravitate to be more compact. Canova and Dallari (2013) provide the effect of the pandemic shock to the tourism-depended countries. The results confirmed that pandemic shock caused the absence of tourism channel and according to that, the output effects were reduced by about one-fourth. Škare et al. (2020) estimated the impact of the COVID-19 crisis on the tourism sector. The results confirmed that recovery of the tourism, especially hospitality sector, will take more time than the average expected recovery period of 10 months. From that point of view, the policy support should insure sustainability of enterprises in touristic industry.

According to the changes in health conditions, new forms of consumer behavior and new ways of consuming tourism are causing new need for hospitality market (Ružić et al., 2011). The prerequisite for re-opening the economies toward travel and tourism is introduction new technologies as the core of solutions for combing the health's and economic's requirements. The mobility tracing applications, robotised service delivery, digital health passports and identity controls will ensure social distancing and provide health conditions to prevent infection (Sigala, 2020).

On the other hand, the introduction of new technologies, will make business processes more expensive. Various political and commercial decisions have been made, and the time will show the impact of these decisions in the economic context to the sustainability of the hospitality and tourism environment (Baum, 2020). The several crises already showed that is necessary to apply sustainable tourism development by "connecting regenerative agriculture and transformative tourism" (Ateljević, 2020, p. 436).

Despite the enormous negative consequences of COVID-19 shock, this pandemic crisis has given the tourism industry an opportunity for turning its focus away from haphazard development to sustainable and mindful 
consumption of a tourist product (Nepal, 2020). After global pandemic crisis, everybody is given an opportunity to transform the tourism from global and massive trend toward individual and special tourist experience what contribute to sustainable development growth in touristic industry (Gössling et al., 2020). Also, the countries will have to shape the style of rest and travel, diversification of activities on vacation and impose the need for special, planning, shaping and management of touristic products. The combination of natural wealth, cultural heritage and the way of life of the local community, countries create a special form of long-term sustainable tourism (Ružić et al., 2016).

In the period of post-crisis, people's habits will transform the tourism and hospitality industries. New characteristics of touristic demand stand out "four key tourism micro-trends: creative tourism, off-the-beaten-track tourism, alternative accommodation and fully digital tourism" (Ketter, 2020 , p. 1). The tourism of the future should design services in environmentally friendly and sustainable approach. Dolnicar (2020) offered example of how the tourism industry can diminish environmental damage by actively designing brand-owned touch points. In that way, all stakeholders behave more environmentally friendly and contribute to the long-term sustainability of the tourism sector. The type of tourism that can resist future shocks and crises is tourism that offers services with conceptual solutions and destinations that consider sustainability as a part of the image (Melkić et al., 2020). Grilli et al. (2021) show that the exploitation the natural resources for tourism purposes in long-term period will cause trade-off between economic value and sustainability.

Policy makers should consider pro-environmental attitudes to maintain balance between ecosystem services and social and cultural identities. Yang et al. (2020) set DSGE model that implied blocks; four health disaster risk, utility function, health investment, and production. The results confirmed that health status influences labor productivity and that decline in health status caused lower tourism and generic outputs. From this point of view, tourism sector has to be financed by resources redistributed from other sectors.

The three main components of new age of tourism are 1) focus on domestic demand in the short term, due to health barriers (Lapointe, 2020), 2) transforming destinations from "Growth for development" to "Degrowth for livability" (Renaud, 2020) and 3) tourism socialization "based on the 
interests of local communities and local people" (Higgins-Desbiolles, 2020, p. 437).

To recover as quickly as possible and start the rise in the economy, the government will have to put extra effort through both fiscal and monetary measures. The various of tax relaxing mechanism are necessary to apply in coordination with unconventional and macroprudential policy (PopekBiškupec \& Bilal-Zorić, 2017). In period of vulnerable situation and lack of financial power, the financial help is needed to maintain the tourism sector active. The responsibility also lies with the central bank, which can use macroprudential instruments to launch credit cycles and help the real sector recover faster.

The quantitative analysis of the effects and scale of the impact the pandemic crisis on the entire economy is necessary for strategic decision makers and bringing the strategies for the development of countries with significant touristic sector. From that point of view, regulators and decision makers should constantly observe relationships of tourism and economic growth. Khan et. al., (2020) used various econometric tools for analyzing the connection of tourism and economic growth of developing countries. The research confirmed the causal relationships of tourism with economic growth, energy, agriculture development and poverty. The study proved that tourism has important role in the development of emerging economies.

The results of the research confirm that a $1 \%$ increase in tourism significantly enhances gross domestic product (GPD) by $0.051 \%$, foreign direct investment by $2.647 \%$, energy development by $0.134 \%$, agriculture development by $0.26 \%$, and reduces poverty by $0.51 \%$ in the long run. Farzanegan et al. (2020) made cross-country regression analysis that was referring to the correlation between international tourism and COVID-19 confirmed cases. The research confirmed positive correlation between international tourism and confirmed cases of COVID-19 disease in period till April 30, year 2020. The authors estimated that the $1 \%$ higher level of inbound and outbound tourism is associated with $1.2 \%$ and $1.4 \%$ higher levels of confirmed COVID-19 cases.

Special attention should be paid to developing countries that have a large share of the tourism sector in the economy, like Croatia. Such countries are vulnerable to all kinds of shocks and have more difficult adaptation to structural difficulties. Finally, these countries need much more time to achieve macroeconomic balances after a crisis or recession. 


\section{Data analysis}

Croatia as the tourism-depended country has suffered huge losses due to the lockdowns in the period of COVID-19 crisis.

Figure 1: Nights spent in tourist accommodation in Croatia (\% change compared with same period of previous year)

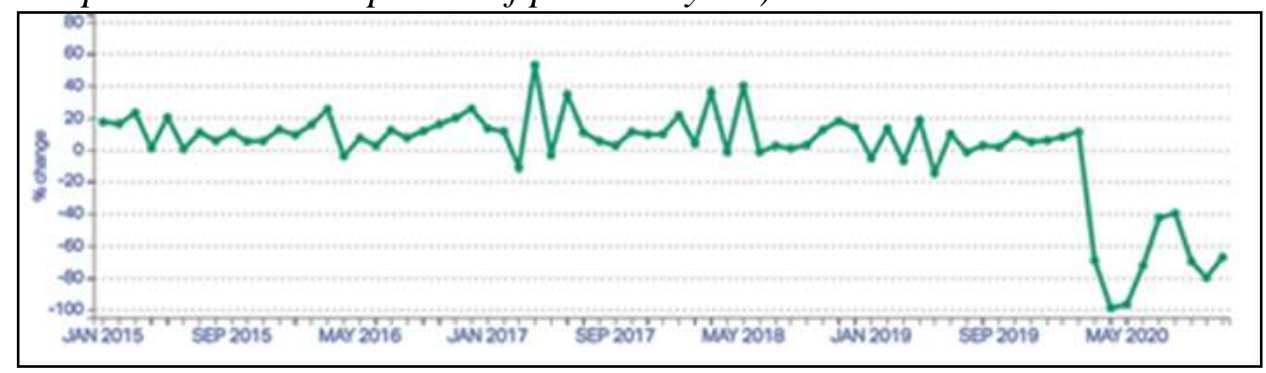

Source: Eurostat, (2020), COVID-19: Statistics serving Europe, https://ec.europa.eu/eurostat/cache/recovery-dashboard/, (28 February 2021)

As Figure 1 presents, the sudden drop of the nights spent in tourist accommodation in Croatia was noticed since beginning of the year 2020.

Figure 2: CROBEXturist index in the period 01 Feb 2019-01 Feb 2021

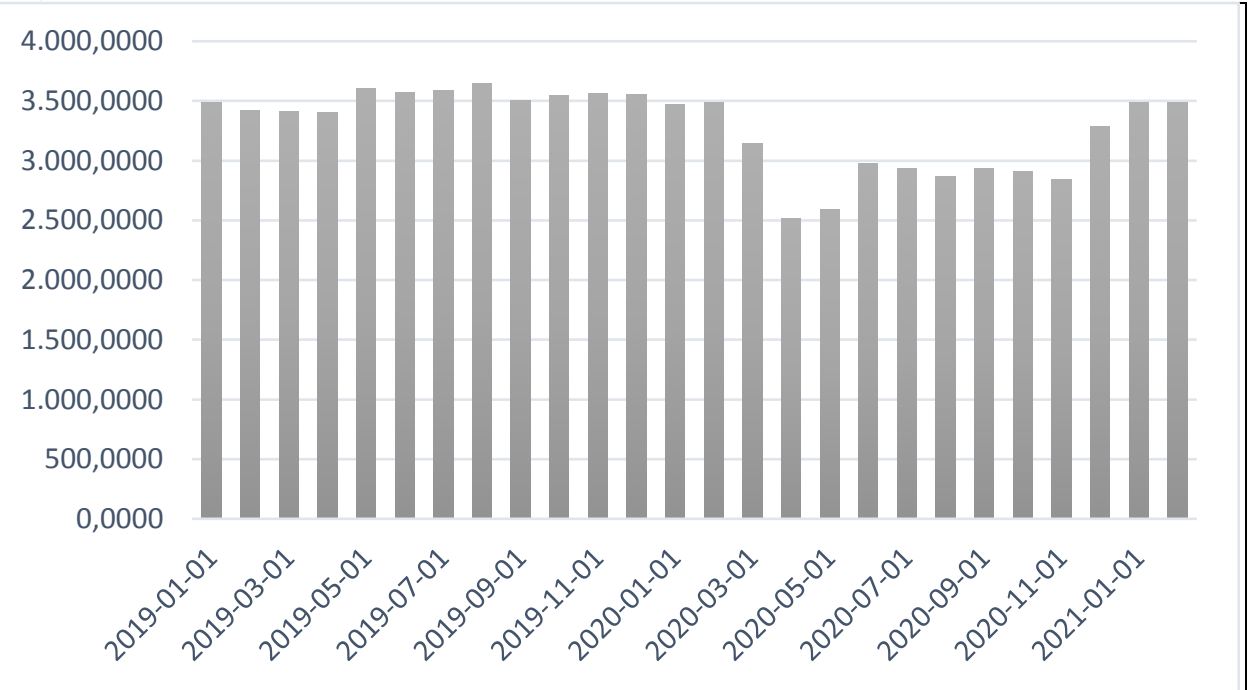

Source: Authors' calculation according to the Zagreb Stock Exchange (2020) data, https://zse.hr/hr/indeks/365?isin=HRZBOOICBTUO\&tab= index_history\&date_from $=2019-01-01 \&$ date_to $=2021-02-26$, (20 February 2021) 
In this paper, CROBEXturist index is considered as the indicator of trends in tourism sector. The changes of the index show the impact of pandemic and the perception of the future market trends. The data analysis confirms the structural shock in March 2020, caused by pandemic. Due to the fact that Croatia is tourism-dependent country, the shock in this sector has spilled over to all segments of the economy.

This paper analyses the impact of pandemic on the touristic sector using Structural vector autoregressive model (SVAR). The COVID-19 shock was approximated by periods of lockdowns in Croatia, and it was introduced in model as dummy variable. The losses in touristic sector were presented by drop of CROBEXturist index. CROBEXturist index is sectoral index that refers to the hotel industry. The data were collected from the March 2019 till December 2020 on daily basis (Zagreb Stock Exchange, 2020).

Before constructing the SVAR model, the analysis of causality is conducted using Granger test. The Granger causality test is a statistical hypothesis test for analyzing the usefulness one time series in forecasting another (Rossi, 2013).

First step is to check the stationary of variables using ADF test. The results are shown in Table 1.

Table 1: Augmented Dickey- Fuller test

\begin{tabular}{|l|l|l|l|l|}
\hline Variable & Lag Length & t-statistic ADF & p & Test for unit root: \\
\hline croindx & (SIC) 2 & -9.536 .677 & 0.0000 & In $1^{\text {st }}$ difference with intercept \\
\hline turn & (SIC) 4 & -5.472 .735 & 0.0000 & In level with intercept \\
\hline lock & (SIC) 0 & -2.266 .418 & 0.0000 & In $1^{\text {st }}$ difference with intercept \\
\hline
\end{tabular}

Source: Authors' calculation

Due to the unit root test, variable croindxis stationary in its level with intercept included and variables turn and lock are stationary in their first differences with intercept included.

After conducting ADF test, it is necessary to analyze the causality between variables. To test the causality, it is needed to check if variable $\mathrm{x}$ (lock)causes variables y (croindx and turn). If $x$ causes y, it is possible to determine the optimal information set used to forecast $y$. The most used solution is testing the causality from variable $\mathrm{x}$ observed for the $i^{\text {th }}$ to the variable y observed for the $j^{\text {th }}$ with $\mathrm{j}=\mathrm{i}$ or $\mathrm{j} \neq \mathrm{i}$. Granger causality refers to 
determining if one variable has impact to the present and future trends of another variable (Granger, 1969).

Table 2: Granger causality test

\begin{tabular}{|c|c|c|c|}
\hline Null Hypothesis & Obs & F-Statistic & Prob. \\
\hline LOCK does not Granger Cause CROINDX & 510 & 281.584 & 0.0105 \\
\hline \multicolumn{2}{|l|}{ CROINDX does not Granger Cause LOCK } & 646.962 & 1.E-06 \\
\hline TURN does not Granger CauseCROINDX & 510 & 146.915 & 0.1868 \\
\hline \multicolumn{2}{|l|}{ CROINDX does not Granger Cause TURN } & 0.70646 & 0.6445 \\
\hline TURN does not Granger Cause LOCK & 510 & 0.74097 & 0.6168 \\
\hline \multicolumn{2}{|l|}{ LOCK does not Granger Cause TURN } & 0.19798 & 0.9773 \\
\hline
\end{tabular}

Source: Authors' calculation

The Granger test reject the null hypothesis that lock does not cause croindx, what means that pandemic shock has impact on CROBEXturist index. The results confirmed the thesis that lockdown had significant impact on tourist sector and caused downturn in hotel industry business.

\section{The specification of VAR model}

In the recent period, the Vector autoregressive models became the basis of macroeconomic policy analysis, forecasting and testing dynamic stochastic models of general equilibrium (Del Negro \& Schorfheide, 2010). The introduction of shocks in macroeconomic research started with Blanchard and Perotti (2002) and testing the impact of different taxes to the policy strategies.

In this paper, the VAR model includes pandemic shock (lock), turnover (turn)and last value of daily CROBEXturist index (croindx) of Zagreb Stock Exchange trade in touristic sector. The model can be presented as:

$$
V_{t}=z+D(L) V_{t-1}+R_{t}(1)
$$

where $\mathrm{z}=A^{-1} A_{0}, D(L)=A^{-1} C(L)$ and $u_{t}=A^{-1} \varepsilon_{t}$, what represents reduced form of innovation (shocks) which have no direct economic interpretation (Bahovec \& Erjavec, 2009).

Variables in the model are show as vector:

$$
Y_{t}=[\text { lcroind } x, \text { lturn, lock }](2)
$$


The lag length criteria for VAR model is6 according to the Aikike information criterion. Using lag length 6 , the stability of VAR model should be checked. Roots of Characteristic Polynomial for variables croindx, lock, and turn are shown in the table below.

Table 3: VAR stability condition check

\begin{tabular}{|l|l|}
\hline \multicolumn{1}{|c|}{ Root } & \multicolumn{1}{c|}{ Modulus } \\
\hline 0.894207 & 0.894207 \\
\hline$-0.670351-0.454576 \mathrm{i}$ & 0.809945 \\
\hline$-0.670351+0.454576 \mathrm{i}$ & 0.809945 \\
\hline$-0.260889-0.689387 \mathrm{i}$ & 0.737101 \\
\hline$-0.260889+0.689387 \mathrm{i}$ & 0.737101 \\
\hline $0.716233-0.133630 \mathrm{i}$ & 0.728592 \\
\hline $0.716233+0.133630 \mathrm{i}$ & 0.728592 \\
\hline-0.715520 & 0.715520 \\
\hline $0.150775+0.687971 \mathrm{i}$ & 0.704299 \\
\hline $0.150775-0.687971 \mathrm{i}$ & 0.704299 \\
\hline $0.482006-0.493961 \mathrm{i}$ & 0.690165 \\
\hline $0.482006+0.493961 \mathrm{i}$ & 0.690165 \\
\hline $0.268919-0.588325 \mathrm{i}$ & 0.646872 \\
\hline $0.268919+0.588325 \mathrm{i}$ & 0.646872 \\
\hline$-0.394466+0.246971 \mathrm{i}$ & 0.465401 \\
\hline$-0.394466-0.246971 \mathrm{i}$ & 0.465401 \\
\hline$-0.184549-0.400192 \mathrm{i}$ & 0.440695 \\
\hline$-0.184549+0.400192 \mathrm{i}$ & 0.440695 \\
\hline
\end{tabular}

Source: Authors' calculation

AR roots table shows that no root lies outside the unit circle and that VAR satisfies the stability condition because neither value crosses over 1 .

Table 4: Vector Autoregression Estimates (VAR model)

\begin{tabular}{|c|c|c|}
\hline & $\begin{array}{c}\text { Vector Autoregression } \\
\text { Estimates }\end{array}$ & Granger/Wald Test \\
\hline $\begin{array}{c}\text { Dependent Variable } \\
\text { croindx }\end{array}$ & t-statistics & $\mathrm{p}$ \\
\hline Lock & 3.11543 & 0.0080 \\
\hline Turn & -0.89761 & 0.1534 \\
\hline
\end{tabular}

Source: Authors' calculation 
The VAR model confirmed that the pandemic crisis (lock) is very significant. According to the t-statistics (3.11543) it is possible to expect further negative trends in Croatia caused by pandemic crisis.

After the reduced form of VAR is assessed by OLS method, it is necessary to assume coefficients in order to get structural reduced innovations. The LM test showed no serial correlation at lag length 6 according to the Akaike information criterion. To obtain a structural form from the reduced one, data are used outside the sample, like exogenous constraints. The elements of matrix A are known if the relationship of structural and reduced innovation is known. (Bahovec \& Erjavec, 2009)

Identifying pandemic shocks is determined by restricting the matrix of structural long run multipliers:

$$
A A^{\prime}=\sum\left(\varepsilon_{t}, \varepsilon_{t}{ }^{\prime}\right)(3)
$$

where $\mathrm{A}$ is $n \times n$ matrix and $\varepsilon_{t}$ ispandemic shock that follow normal distribution with mean value (expectation) of zero and unit variance.

Table 1: The Structural VAR Estimates (SVAR model)

\begin{tabular}{|c|c|c|c|c|}
\hline & Coefficient & Std. Error & z-Statistic & Prob. \\
\hline $\mathrm{C}(1)$ & 1.308 .340 & 0.041006 & 3.190 .611 & 0.0000 \\
\hline $\mathrm{C}(2)$ & -1.224 .811 & 0.168416 & -7.272 .522 & 0.0000 \\
\hline $\mathrm{C}(3)$ & -0.194693 & 0.153244 & -1.270 .478 & 0.2039 \\
\hline $\mathrm{C}(4)$ & 3.699 .623 & 0.115953 & 3.190 .611 & 0.0000 \\
\hline $\mathrm{C}(5)$ & 2.337 .235 & 0.134463 & 1.738 .196 & 0.0000 \\
\hline $\mathrm{C}(6)$ & 2.543 .928 & 0.079732 & 3.190 .611 & 0.0000 \\
\hline
\end{tabular}

Source: Authors' calculation

For estimation of SVAR model, the number of constraints should be set in the appropriate matrices. The SVAR model was conducted with CROBEXturist index (croindx) response to the pandemic crisis (lock) variable for the recursive long-run impulse response. Cholesky decomposition identified orthogonal innovations (shocks). Using analytic Response standard errors, the Impulse Function Responses are given below. 
Figure 2: Response to Cholesky One S.D. (d.f. adjusted) Innovations +- 2 S. E.
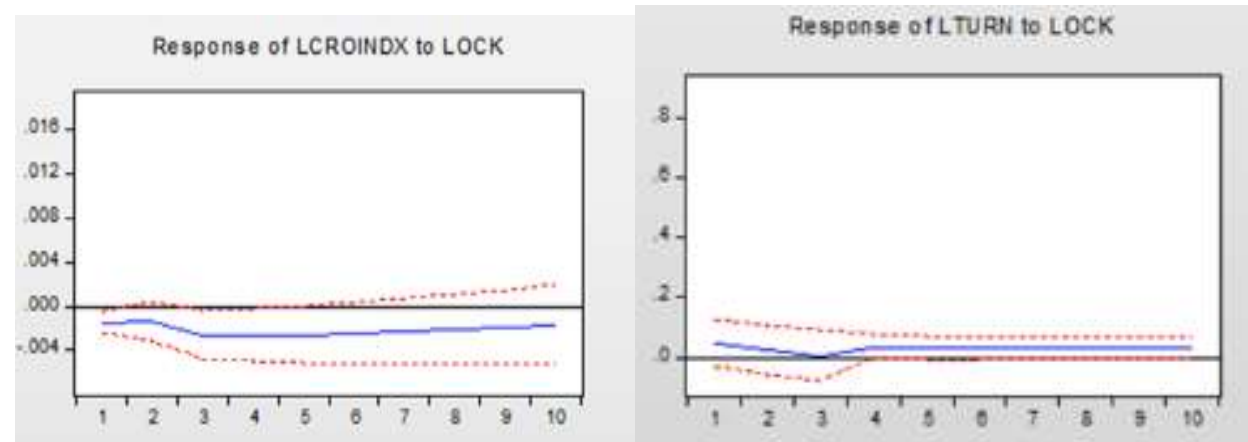

Source: Authors' calculation

The impulse response functions confirm the strong impact on touristic industry, especially in the hospitality sector. The perception of the negative trend was higher at the begging of the crises for the investors, but shock for turnover of hotel industry had stronger impact in the second half of the crisis.

\section{Conclusion}

The COVID-19 pandemic caused enormous losses in all economies and especially in the tourism-depended countries. Many authorities and researchers are dealing with the pandemic phenomenon and everybody is searching for the best policy mechanism to suppress the virus and at the same time to recover economy. This paper provided scientific evidence of vulnerabilities of the tourism sector on the pandemic shock.

The SVAR model confirms the large-scale shock in the touristic sector in Croatia and implicates the importance of measuring shock in assessing future trends and proposing measures for economic recovery. The results show two-phase shock effect. In the first period, the shock is stronger because of risk perception and affects the CROBEXturist index, and in the second part of the observed period, pandemic has stronger impact on turnover of hotel industry in Croatia. The results are according to the expectations. The findings are useful as the confirmation of the necessity for stronger macroeconomic policy measures, both fiscal and monetary regulators, due to the recovery of the tourism sector. 
The research was conducted for the period of coronavirus appearance. Due to the relatively short period of time, the results of the model are slightly weaker, so in further research it is recommended to monitor the development of the situation. In addition, it is recommended to continuously test the impact of the pandemic for overall shock on the tourism sector. A similar model can be tested for all entities in the tourism industry and analog this research, the analysis could be performed for subjects and services within touristic offer.

\section{References}

1. Arčabić, V. (2020). Koronakriza i što Hrvatska može naučiti iz dosadašnjih recesija. Tradicionalni skup Hrvatskog društva ekonomista u Opatiji-objavljena poglavlja, Zagreb, 28, 21-58.

2. Ateljević, I. (2020). Transforming the (tourism) world for good and (re)generating the potential 'new normal'. Tourism Geographies, Vol. 22, No. 3, 467-475.

3. Bahovec, V., Erjavec, N. (2009). Uvod u ekonometrijsku analizu, Element, Zagreb.

4. Bakar, A. A., Rosbi, S. (2020). Effect of Coronavirus disease (COVID19) to tourism industry. International Journal of Advanced Engineering Research and Science (IJAERS), Vol. 7, No. 4,189-193.

5. Baum, T., Hai, N. T.T. (2020). Hospitality, Tourism, Human Rights and the impact of COVID-19. International Journal of Contemporary Hospitality Management, Vol. 32, No. 7, 2397-2407.

6. Blanchard, O. J., Perotti, R. (2002). An Empirical Characterization of the Dynamic Effects of Changes in Government Spending and Taxes on Output. Quarterly Journal of Economics, Vol. 117, No. 4, 1329-1368.

7. Brida, J.G., Gomez, D. M., Segarra, V. (2020). On the empirical relationship between tourism and economic growth. Tourism Management, Vol. 81, 104131.

8. Canova, F., Dallari, P. (2013). How important is tourism for the international transmission of cyclical fluctuations? Evidence from the Mediterranean, European Central Bank, Frankfurt am Main, Germany. 
9. Čavrak, V. (2020). Makroekonomija krize COVID19 i kako pristupiti njenom rješavanju. EFZG Working Paper Series, Vol. 20, No. 3, 1-19.

10. Del Negro, M., Schorfheide, F. (2010), Bayesian Macroeconometrics Handbook of Bayesian Econometrics, https://faculty.wcas.northwestern.edu/ lchrist/course/Korea_2016/del_ne gro_schorfheide.pdf, (12 February 2021).

11. Dolnicar, S. (2020). Designing for more environmentally friendly tourism. Annals of Tourism Research, Vol. 84, 102933.

12. Eurostat, (2020), COVID-19: Statistics serving Europe, https://ec.europa.eu/eurostat/cache/recovery-dashboard/, (28 February 2021).

13. Farzanegan, M.R., Gholipour, H. F., Feizi, M., Nunkoo, R. Andargoli, A.E. (2020). International Tourism and Outbreak of Coronavirus (COVID19): A Cross-Country Analysis. Journal of Travel Research, Vol. 60, No. 3, 687-692.

14. Goretti, M., Leigh, L., Babii, A., Cevik, S., Kaendera, S., Muir, D. Nadeem, S., Salinas, G. (2021). Economic Challenges and Opportunities for Asia-Pacific and the Western Hemisphere, International Monetary Fund, Washington.

15. Gössling, S., Scott, D., Hall, M. (2020). Pandemics, tourism and global change: a rapid assessment of COVID-19. Journal of Sustainable Tourism, Vol. 29, No. 1, 1-20.

16. Granger, C.W. (1969). Investigating Causal Relations by Econometric Models and Cross-Spectral Methods. Econometrica, Vol. 37, No.3, 424438.

17. Grilli, G., Tyllianakis, E., Luisetti, T. Ferrini, S., Turner, K. (2021). Prospective tourist preferences for sustainable tourism development in Small Island Developing States. Tourism Management, Vol. 82, 104178.

18. Higgins-Desbiolles, F. (2020). Socialising tourism for social and ecological justice after COVID-19. Tourism Geographies, Vol. 22, No. 3, 610-623. 
19. Ketter, E. (2020). Millennial travel: tourism micro-trends of European Generation Y. Journal of Tourism Futures, (ahead-of-print), https://www.emerald.com/insight/content/doi/10.1108/JTF-10-20190106/full/html, (26 February 2021).

20. Khan, A., Bibi, S., Lorenzo, A., Lyu, J., Babar, Z.U. (2020). Tourism and Development in Developing Economies: A Policy Implication Perspective. Sustainability, Vol. 12, No. 4, 1618.

21. Lapointe, D. (2020). Reconnecting tourism after COVID-19: the paradox of alterity in tourism areas. Tourism Geographies, Vol. 22, No. 3, 633-638.

22. Mekharat, N., Traore, N. (2020), How the Tourism Sector in Emerging Markets is Recovering from COVID-19, https://www.ifc.org/wps/wcm/ connect/publications_ext_content/ifc_external_publication_site/publicatio ns_listing_page/how+the+tourism+sector+in+emerging+markets+is+reco vering+from+covid-19, (12 April 2021).

23. Melkić, S., Marković-Vukadin, I., Roknić, L. (2020). Održivi turizam - samozavaravanje, ideja ili realnost?. Communication Management Review, Vol. 5, No. 1, 48-83.

24. Nepal, S. K. (2020). Adventure travel and tourism after COVID19 business as usual or opportunity to reset?. Tourism Geographies, Vol. 22, No. 3, 646-650.

25. Newsome, D. (2020). The collapse of tourism and its impact on wildlife tourism destinations. Journal of Tourism Futures, (ahead-of-print), https://www.researchgate.net/publication/342195548_The_collapse_of_to urism_and_its_impact_on_wildlife_tourism_destinations, (20 February 2021).

26. Popek-Biškupec, P. (2015). Utjeca jmakroprudencijalnih instrumenata na kreditnu aktivnost banaka u zemljama Srednje i Istočne Europe. Zbornik Ekonomskog fakulteta u Zagrebu, Vol. 13 No. 2, 85-101.

27. Popek-Biškupec, P., Bilal-Zorić, A. (2017). Optimizacija korištenja instrumenata monetarne i makroprudencijalne politike u svrhu očuvanja stabilnosti financijskog sustava. Zbornik Ekonomskog fakulteta u Zagrebu, Vol. 15, No. 1., 31-49. 
28. Praščević, A. (2020). Ekonomski šok pandemije Covid 19 -prekretnica u globalnim ekonomskim kretanjima. Ekonomske ideje i praksa, No. 37, 722.

29. Renaud, L. (2020). Reconsidering global mobility - distancing from mass cruise tourism in the aftermath of COVID-19. Tourism Geographies, Vol. 22, No. 3, 679-689.

30. Rossi, B. (2013). Handbook of Economic Forecasting, North Holland, Amsterdam.

31. Ružić, D., Andrlić, B, Ružić, I. (2011). Web 2.0 promotion techniques in hospitality industry. International Journal of Management Cases, Vol. 13, No. 4, $310-319$.

32. Ružić, I., Bosnić, I., Kelić, I. (2016). River Cruise as tourism product: Marketing approach. Interdisciplinary management research conference, Opatija, 12, 339-362.

33. Sigala, M. (2020). Tourism and COVID-19: Impacts and implications for advancing and resetting industry and research. Journal of Business Research, Vol. 117, 312-321.

34. Škare, M., Soriano, D. R., Porada-Rochon, M. (2020). Impact of COVID-19 on the travel and tourism industry. Technological Forecasting \& Social Change, Vol. 163, 120469.

35. Uğur, N.G., Akbiyık, A. (2020). Impacts of COVID-19 on global tourism industry: A cross-regional comparison. Tourism Management Perspectives, Vol. 36, 100744.

36. Yang, Y., Zhang, H., Chen, X. (2020). Coronavirus pandemic and tourism: Dynamic stochastic general equilibrium modeling of infectious disease outbreak. Annals of tourism research Vol. 83, 102913.

37. Zagreb Stock Exchange, (2020), CROBEXturist, https://zse.hr/hr/ indeks/365?isin=HRZB00ICBTU0\&tab=index_history, $\quad(02$ February 2021). 